\title{
PECULIARITIES OF IONIC TRANSPORT OF OXYGEN VACANCY CONDUCTING SUPERIONIC CERAMICS
}

\author{
A. Kežionis ${ }^{\text {a }}$, T. Šalkus ${ }^{\text {a }}$, A. Petraitis ${ }^{\text {a }}$, J. Dudonis ${ }^{\text {b }}$, G. Laukaitis $^{\text {b }}$, D. Milčius ${ }^{\text {c }}$, \\ V. Kazlauskiené ${ }^{\mathrm{d}}$, J. Miškinis ${ }^{\mathrm{d}}$, and A.F. Orliukas ${ }^{\mathrm{a}}$ \\ ${ }^{a}$ Faculty of Physics, Vilnius University, Saulètekio 9, LT-10222 Vilnius, Lithuania \\ E-mail: tomas.salkus@ff.vu.lt \\ ${ }^{\mathrm{b}}$ Kaunas University of Technology, Studentu 50, LT-51368 Kaunas, Lithuania \\ ${ }^{\mathrm{c}}$ Lithuanian Energy Institute, Breslaujos 3, LT-44403 Kaunas, Lithuania \\ ${ }^{\mathrm{d}}$ Institute of Materials Science and Applied Research, Vilnius University, Naugarduko 24, LT-03225 Vilnius, Lithuania
}

Received 10 June 2009; revised 8 September 2009; accepted 15 September 2009

\begin{abstract}
The powder of $\mathrm{Zr}_{0.92} \mathrm{Y}_{0.08} \mathrm{O}_{2}$ (YSZ), $\mathrm{Ce}_{0.9} \mathrm{Gd}_{0.1} \mathrm{O}_{2-\delta}$ (GDC) and $\mathrm{Sm}_{0.15} \mathrm{Ce}_{0.85} \mathrm{O}_{2-\delta}$ (SDC) compounds from the company Fuel Cell Materials were used for sintering of ceramic samples in air at temperature $T=1673 \mathrm{~K}$. The surface of the prepared ceramics was studied by scanning electron microscopy (SEM) and X-ray photoelectron spectroscopy (XPS). Results of the performed XPS investigations revealed that cerium exists as $\mathrm{Ce}^{3+}$ and $\mathrm{Ce}^{4+}$ in both the $\mathrm{Ce}_{0.9} \mathrm{Gd}_{0.1} \mathrm{O}_{2-\delta}$ and $\mathrm{Sm}_{0.15} \mathrm{Ce}_{0.85} \mathrm{O}_{2-\delta}$ ceramics. XPS spectra of $\mathrm{O} 1 \mathrm{~s}$ of all the investigated materials demonstrated two peaks corresponding to oxygen $\mathrm{O}(1)$ in crystal lattice and to adsorbed oxygen $\mathrm{O}(2)$. Measurements of complex impedance, electric conductivity, dielectric permittivity, and $\tan \delta$ of dielectric losses were carried out in frequency range $10^{6}-1.2 \cdot 10^{9} \mathrm{~Hz}$ at temperatures ranging from $300 \mathrm{~K}$ to $700 \mathrm{~K}$. Relaxation dispersion of the electric parameters has been found for all the compounds. The dispersion is caused by the oxygen vacancy $\left(\mathrm{V}_{\mathrm{O}} \bullet \bullet\right)$ transport in grains of the ceramic samples.
\end{abstract}

Keywords: YSZ, GDC, SDC ceramics, solid oxide fuel cells, ionic conductivity

PACS: $81.15 . J j$, 66.30.Dn, 82.47.Ed, 73.61.-r

\section{Introduction}

Solid electrolytes (SE) with fast oxygen vacancies' $\left(\mathrm{V}_{\mathrm{O}} \bullet \bullet\right)$ transport are attractive materials for applications in solid oxide fuel cells (SOFC) [1,2]. Yttria stabilized zirconia $\mathrm{Zr}_{0.92} \mathrm{Y}_{0.08} \mathrm{O}_{2}$ (YSZ) is the most important SE in SOFCs operating in the high temperature regime. At temperature $T=1073 \mathrm{~K}$ in the low frequency range $\left(10-10^{5} \mathrm{~Hz}\right)$, the value of total conductivity of YSZ was found to be $\sigma_{t}=1.31 \mathrm{~S} / \mathrm{m} \mathrm{[3]}$. The bulk conductivity of polycrystalline YSZ thin films deposited by e-beam technique at temperature $660 \mathrm{~K}$ was found to be $\sigma_{\mathrm{b}}=$ $4.12 \cdot 10^{-3} \mathrm{~S} / \mathrm{m}$ (its activation energy $\Delta E_{\sigma}=0.95 \mathrm{eV}$ ) and depended on technological conditions of the films' deposition [4]. One way to lower the operating temperature is to use a $\mathrm{SE}$ with higher $\mathrm{V}_{\mathrm{O}}$ •• conductivity, such as gadolinia doped ceria (GDC) and Sm-doped ceria (SDC). At temperature $T=923 \mathrm{~K}$ the values of ionic conductivity of $\mathrm{Ce}_{0.8} \mathrm{Gd}_{0.2} \mathrm{O}_{2-\delta}$ and $\mathrm{Ce}_{0.8} \mathrm{Sm}_{0.2} \mathrm{O}_{2-\delta}$ were found to be $2.6 \mathrm{~S} / \mathrm{m}\left(\Delta E_{\sigma}=0.95 \mathrm{eV}\right)$ and $3.8 \mathrm{~S} / \mathrm{m}\left(\Delta E_{\sigma}=0.75 \mathrm{eV}\right)$ respectively [5]. At the temperature $T=973 \mathrm{~K}$ the value of the conductivity of commercial (CP) and synthesized (SP) polycrystalline $\mathrm{Ce}_{0.8} \mathrm{Gd}_{0.2} \mathrm{O}_{1.9}$ samples was found to be $2.6 \mathrm{~S} / \mathrm{m} \mathrm{[6]}$. At $T=973 \mathrm{~K}$ the values of the bulk conductivity of $\mathrm{Ce}_{0.85} \mathrm{Gd}_{0.15} \mathrm{O}_{1.925}$ and $\mathrm{Ce}_{0.85} \mathrm{Sm}_{0.15} \mathrm{O}_{1.925}$ ceramics reach $20.9 \mathrm{~S} / \mathrm{m}\left(\Delta E_{\sigma}=0.7 \mathrm{eV}\right)$ and $9.1 \mathrm{~S} / \mathrm{m}\left(\Delta E_{\sigma}=\right.$ $0.69 \mathrm{eV})$ respectively [7]. The electric conductivity of $\mathrm{Ce}_{0.9} \mathrm{Gd}_{0.1} \mathrm{O}_{1.95}$ in a reducing atmosphere has electronic and ionic components. The value of electronic component is caused by the mixed $\mathrm{Ce}^{4+} / \mathrm{Ce}^{3+}$ valence in the GDC compound [8]. The above-mentioned investigations of electric conductivity of SE were performed in low frequency range from $10^{-3}$ to $10^{6} \mathrm{~Hz}$. The results of X-ray photoelectron spectroscopy (XPS) investigation of SDC have shown that spectra of O 1s consisted of double peaks [9]. The two peaks represented oxygen $\mathrm{O}(1)$ in crystal lattice and an adsorption oxygen $\mathrm{O}(2)$. The binding energy of $\mathrm{O}(1)$ is lower than that of $\mathrm{O}(2)$ [9]. The authors of [10] reported that in GDC thin films prepared by spray pyrolysis, in XPS spectra in the $\mathrm{Ce} 3 \mathrm{~d}$ region the different lines belonging to $\mathrm{Ce} 3 \mathrm{~d}_{3 / 2}$ and Ce $3 \mathrm{~d}_{5 / 2}$ exist. The oxygen $\mathrm{O} 1$ s core 
Table 1. YSZ, GDC, and SDC composition, surface area (BET) of the powder, and relative density of the ceramics.

\begin{tabular}{lcc}
\hline Composition & BET, $\mathrm{m}^{2} / \mathrm{g}$ & $d, \%$ \\
\hline $\mathrm{Ce}_{0.85} \mathrm{Sm}_{0.15} \mathrm{O}_{2-\delta}$ & 195 & 94 \\
$\mathrm{Ce}_{0.9} \mathrm{Gd}_{0.1} \mathrm{O}_{2-\delta}$ & 201 & 85 \\
$\mathrm{Zr}_{0.92} \mathrm{Y}_{0.08} \mathrm{O}_{2}$ & 129 & 93 \\
\hline
\end{tabular}

level spectra depend on the sputtering time of GDC thin films [10]. In the XPS spectra of YSZ the O 1s signal can be resolved into two peaks, where the main peak at a binding energy of $529.4 \mathrm{eV}$ belongs to the lattice oxygen and a smaller one at $531.8 \mathrm{eV}$ can be ascribed to the adsorbed oxygen [11]. The high ionic conductivity of these SE and peculiarities of the ionic migration stimulate further investigations of the ionic transport properties in a wide frequency range. Investigation of the electric properties of materials with fast ion transport at high frequencies provides unique information on mass and charge transport, polarization phenomena, and relaxation processes in such systems. In this paper, we report the results of investigation of surfaces by scanning electron microscopy (SEM) and XPS, as well as data on study of complex electrical properties of YSZ, GDC, and SDC ceramics in the frequency range from $10^{6}$ to $1.2 \cdot 10^{9} \mathrm{~Hz}$ and temperature range from 300 to $700 \mathrm{~K}$.

\section{Experiments}

Commercial YSZ, GDC, and SDC powders from the company Fuel Cell Materials were used for sintering of the ceramics. The powder was uniaxially cold-pressed at $150 \mathrm{MPa}$. The sintering of ceramic samples was conducted in air at $T=1673 \mathrm{~K}$. The sintering duration was $1 \mathrm{~h}$. The composition, BET of the powder, and relative density of the ceramics are presented in Table 1.

The scanning electron microscope JSM 5600 was used to investigate the microstructure of surface of the ceramics. The elemental composition of the ceramics' surface was defined by XPS (RIEBER LAS-3000, $\mathrm{X}$-rays with $h \nu=1486.6 \mathrm{eV}$, pressure in chamber $10^{-8} \mathrm{~Pa}$ ). The XPSPEAK41 program was used to fit the experimental spectra. The complex electric conductivity $\tilde{\sigma}=\sigma^{\prime}+\mathrm{i} \sigma^{\prime \prime}$, dielectric permittivity $\tilde{\varepsilon}=\varepsilon^{\prime}-\mathrm{i} \varepsilon^{\prime \prime}$, and impedance $\tilde{Z}=Z^{\prime}-\mathrm{i} Z^{\prime \prime}$ (where intrinsic electrical impedance $\rho^{\prime}=Z^{\prime} S / l, \rho^{\prime \prime}=Z^{\prime \prime} S / l, S$ is electrode area, $l$ is sample length) of the ceramics were investigated in air in the frequency range of $10^{6}-1.2 \cdot 10^{9} \mathrm{~Hz}$ at 300-700 K temperatures by an impedance spectrometer set-up [12].

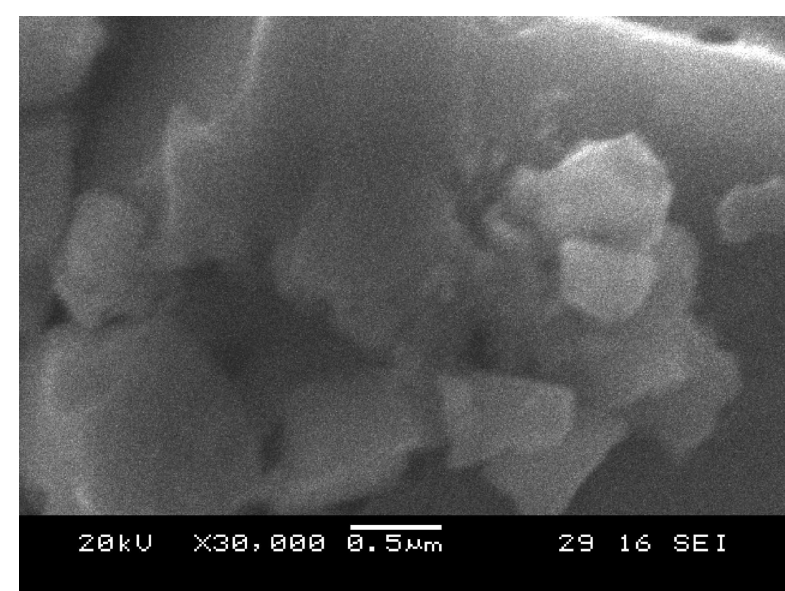

(a)

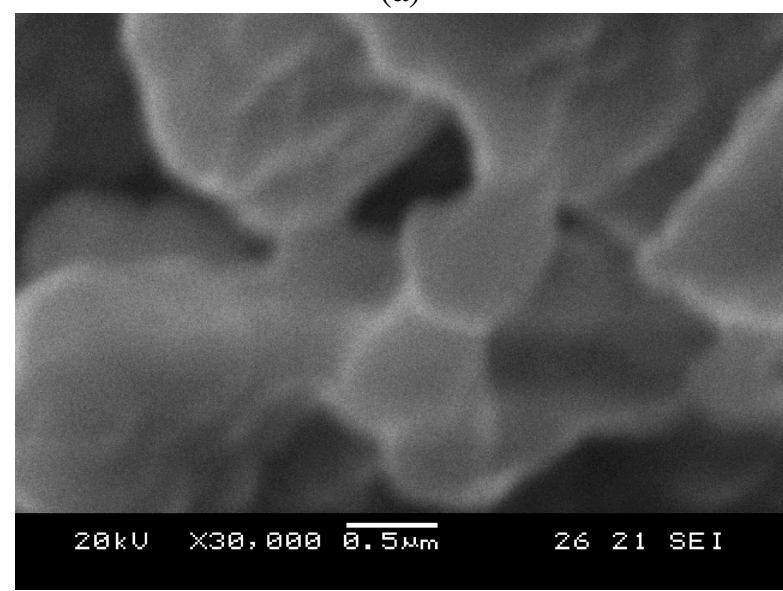

(b)

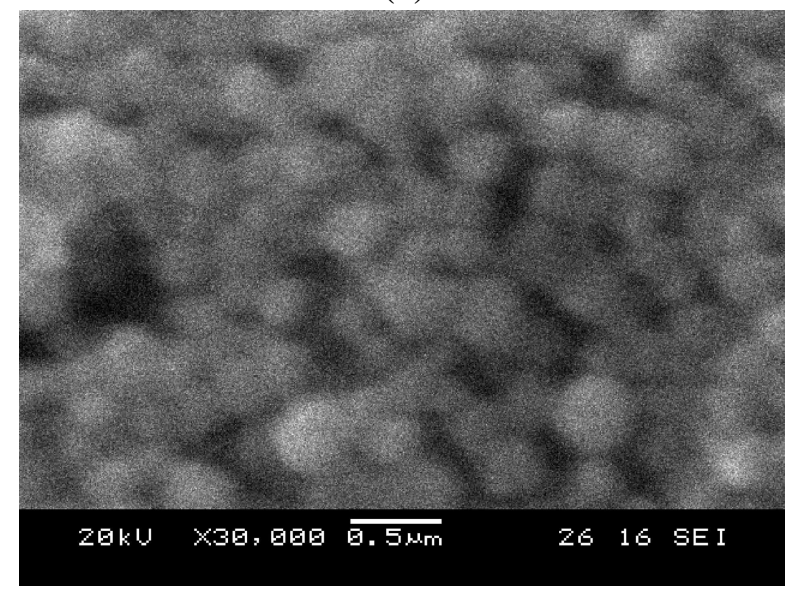

(c)

Fig. 1. SEM images of the surfaces of (a) YSZ, (b) GDC, and (c) SDC ceramics.

\section{Discussion of results}

Characteristic SEM images of the YSZ, GDC, and SDC ceramics' surfaces are shown in Fig. 1 ((a), (b), and (c) respectively). The relative density of SDC ceramic is higher and grain sizes are smaller compared to YSZ or GDC ceramics. 


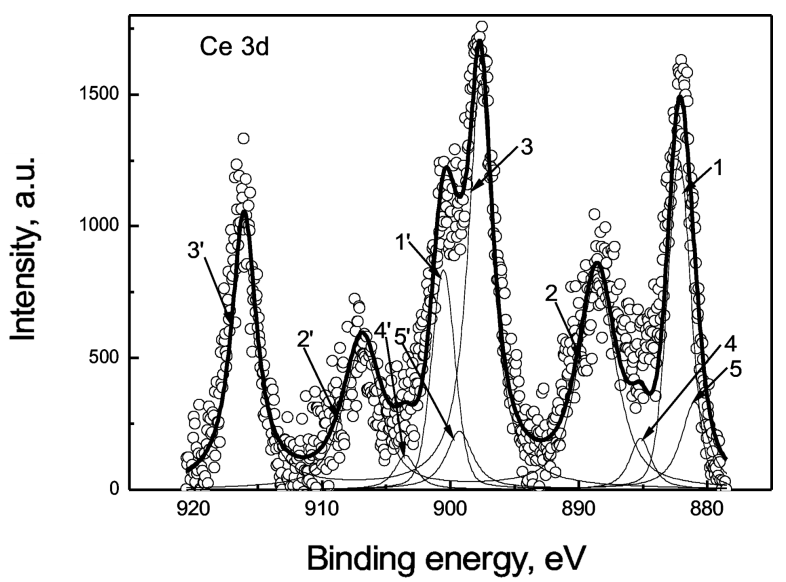

(a)

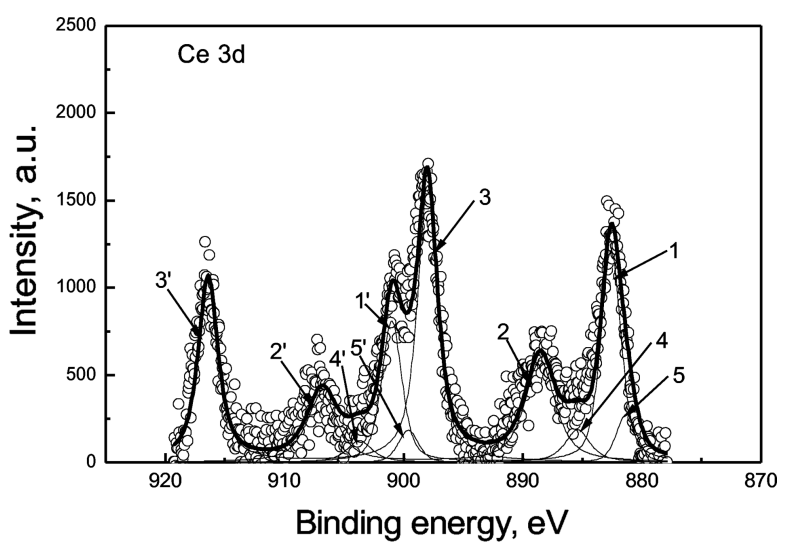

(b)

Fig. 2. Ce 3d XPS spectra of (a) GDC and (b) SDC ceramics.

\begin{tabular}{lcc} 
Table 2. $\mathrm{Ce}^{3+}$ and $\mathrm{Ce}^{4+}$ concentration in \\
GDC and SDC ceramics. \\
\hline Compound & $\mathrm{Ce}^{3+}, \%$ & $\mathrm{Ce}^{4+}, \%$ \\
\hline $\mathrm{Ce}_{0.9} \mathrm{Gd}_{0.1} \mathrm{O}_{2-\delta}$ & 26.6 & 72.5 \\
$\mathrm{Ce}_{0.85} \mathrm{Sm}_{0.15} \mathrm{O}_{2-\delta}$ & 11.62 & 88.38
\end{tabular}

The Ce 3d XPS spectra at room temperature of investigated ceramics are shown in Fig. 2. To exclude any effects on values of binding energies due to the charging of samples during XPS analysis, all data were corrected by a linear shift such that peak maximum of $\mathrm{C} 1 \mathrm{~s}$ binding energy of adventitious carbon corresponded to $284.6 \mathrm{eV}$. The spectra are presented after the background (Shirley background) has been subtracted and the are normalized to the max value [13]. The Ce 3d spectrum is divided into 10 components as shown in Fig. 2(a, b). The lines 4, 4', 5, and 5' appear for $\mathrm{Ce}_{2} \mathrm{O}_{3}$ and $1,1^{\prime}, 2,2$ ', 3, and $3^{\prime}$ appear for $\mathrm{CeO}_{2}$ in GDC and SDC. The concentration of $\mathrm{Ce}^{3+}$ in GDC and SDC can be determined from the equations [14]

$$
\left[\mathrm{Ce}^{3+}\right] \sim S^{4}+S^{4^{\prime}}+S^{5}+S^{5^{\prime}}
$$

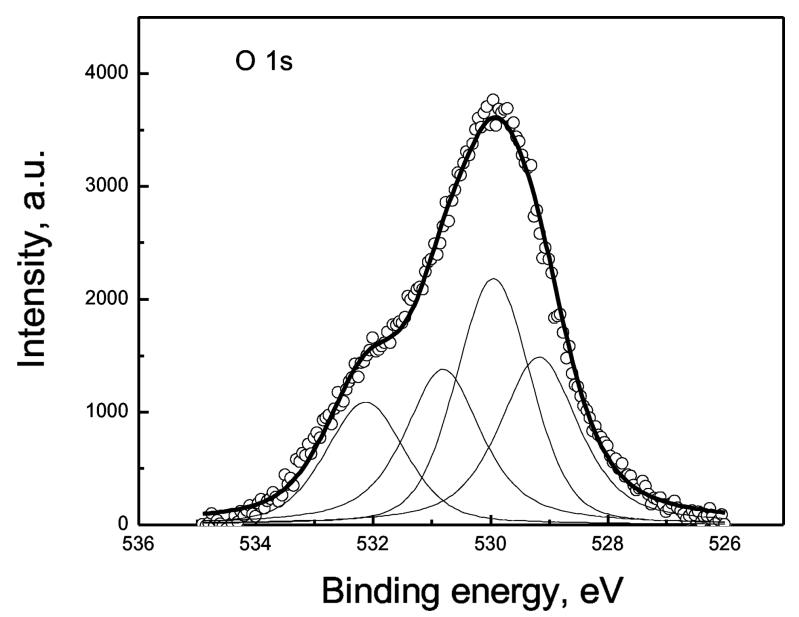

Fig. 3. O 1s X-ray photoelectron spectrum of YSZ.

$$
\begin{aligned}
& {\left[\mathrm{Ce}^{4+}\right] \sim S^{1}+S^{1^{\prime}}+S^{2}+S^{2^{\prime}}+S^{3}+S^{3^{\prime}}, } \\
& {\left[\mathrm{Ce}^{3+}\right] \% }=100 \frac{\left[\mathrm{Ce}^{3+}\right]}{\left[\mathrm{Ce}^{3+}\right]+\left[\mathrm{Ce}^{4+}\right]},
\end{aligned}
$$

where $S^{1}, S^{1^{\prime}}, S^{2}, S^{2^{\prime}}, S^{3}, S^{3^{\prime}}, S^{4}, S^{4^{\prime}}, S^{5}$, and $S^{5^{\prime}}$ are the areas under curves $1,1^{\prime}, 2,2^{\prime}, 3,3^{\prime}, 4,4^{\prime}, 5$, and 5 ' respectively. The concentration of $\mathrm{Ce}^{3+}$ in GDC and SDC is shown in Table 2.

Typical O 1s X-ray photoelectron spectrum of YSZ is shown in Fig. 3. The results of the XPS investigation show that spectra of O 1s of YSZ, GDC, and SDC ceramics consist of double peaks. The two peaks represent oxygen $\mathrm{O}(1)$ in crystal lattice and an adsorption oxygen $\mathrm{O}(2)$ as in $[9,11]$. The binding energies of $\mathrm{O}(1)$ of YSZ, GDC, and SDC are 529.4, 529.4, and $528.6 \mathrm{eV}$ respectively. The binding energies of $\mathrm{O}(2)$ of YSZ, GDC, and SDC were found to be 531.8, 531.05, and $530.9 \mathrm{eV}$ respectively. The elemental compositions of the investigated ceramics have been found from XPS after elimination of $\mathrm{C}-\mathrm{O}, \mathrm{C}=\mathrm{O}$, and $\mathrm{C}-\mathrm{H}$ groups. The elemental compositions are presented in Table 3.

Characteristic frequency dependences of real part of complex electric conductivity $\operatorname{Re}(\sigma)$ of GDC, SDC, and YSZ ceramics at temperature $T=700 \mathrm{~K}$ are presented in Fig. 4.

The dispersion region has been found in the $\operatorname{Re}(\sigma)$ spectra of all investigated ceramics. The dispersion processes are related to ion transport in the bulk of the ceramics. The dispersion process is thermally activated and dispersion regions shift towards higher frequencies with the increase of temperature. The temperature dependences of the bulk electric conductivity were derived from the $\rho^{\prime \prime}\left(\rho^{\prime}\right)$ and $\sigma^{\prime \prime}\left(\sigma^{\prime}\right)$ plots at different temperatures. The $\rho^{\prime \prime}\left(\rho^{\prime}\right)$ plots of GDC, SDC, and YSZ ceramics at temperature $T=700 \mathrm{~K}$ are presented in 
Table 3. Elemental compositions of GDC, SDC, and YSZ compounds.

\begin{tabular}{lcccccc}
\hline Compound & $\mathrm{Zr}, \%$ & $\mathrm{Y}, \%$ & $\mathrm{Ce}, \%$ & $\mathrm{Gd}, \%$ & $\mathrm{Sm}, \%$ & $\mathrm{O}, \%$ \\
\hline $\mathrm{Ce}_{0.85} \mathrm{Sm}_{0.15} \mathrm{O}_{2-\delta}$ & - & - & 16.5 & - & 9.27 & 74.23 \\
$\mathrm{Ce}_{0.9} \mathrm{Gd}_{0.1} \mathrm{O}_{2-\delta}$ & - & - & 16.32 & 5.08 & - & 78.6 \\
$\mathrm{Zr}_{0.92} \mathrm{Y}_{0.08} \mathrm{O}_{2}$ & 22.84 & 6.59 & - & - & - & 70.57 \\
\hline
\end{tabular}

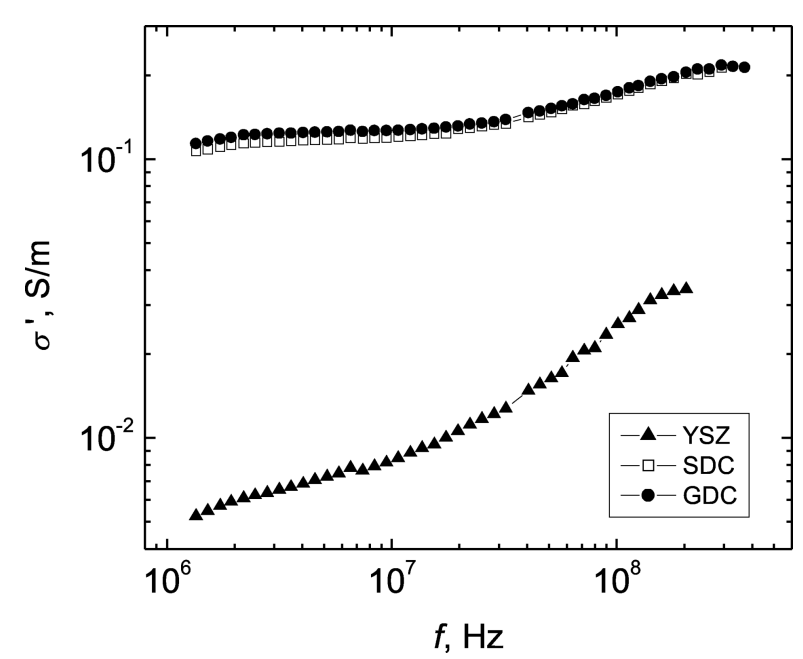

Fig. 4. Frequency dependences of the real part of complex electric conductivity of GDC, SDC, and YSZ ceramics at temperature $T=$ $650 \mathrm{~K}$.

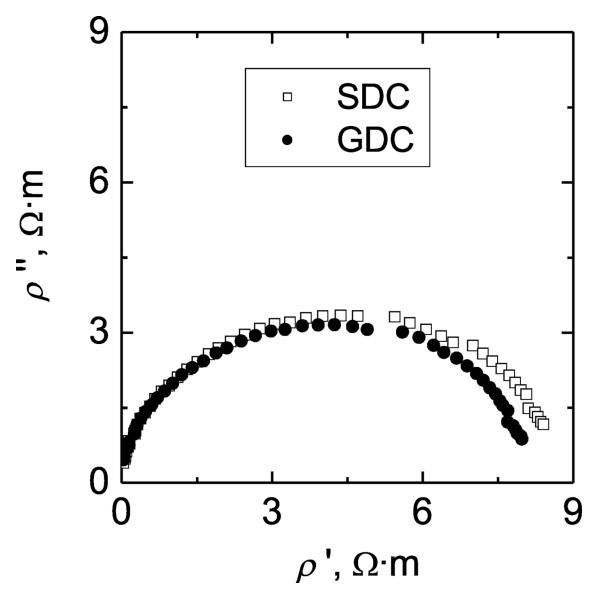

Fig. 5. Complex plane impedance plots of GDC and SDC ceramics at temperature $T=650 \mathrm{~K}$.

Fig. 5. Temperature dependences of the bulk conductivity of investigated ceramics are presented in Fig. 6. Typical temperature dependences of bulk conductivity of investigated ceramics are shown as Arrhenius plots $\left(\log \sigma_{\mathrm{b}}\right.$ against $\left.10^{3} / T\right)$. The values of the bulk conductivity and corresponding activation energies $\Delta E_{\sigma}$ at a $650 \mathrm{~K}$ temperature of the investigated ceramics are presented in Table 4.

The characteristic frequency $f_{\mathrm{b}}$ of the relaxation processes in the bulk at different temperatures is obtained from maxima of the $\operatorname{Im} \rho(f)$ dependences. Characteristic frequency dependences of $\operatorname{Im} \rho$ of GDC ceramics at

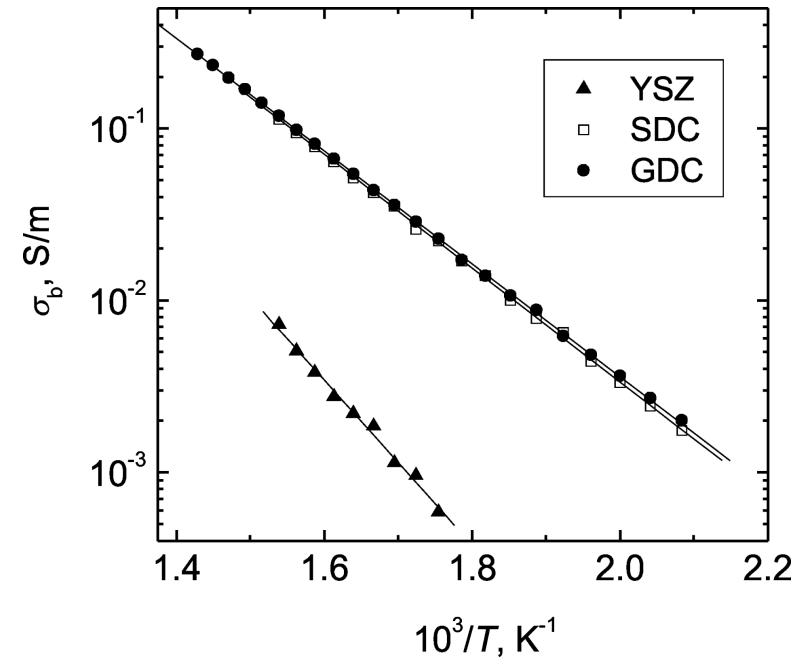

Fig. 6. Temperature dependences of the bulk conductivities of GDC, SDC, and YSZ ceramics.

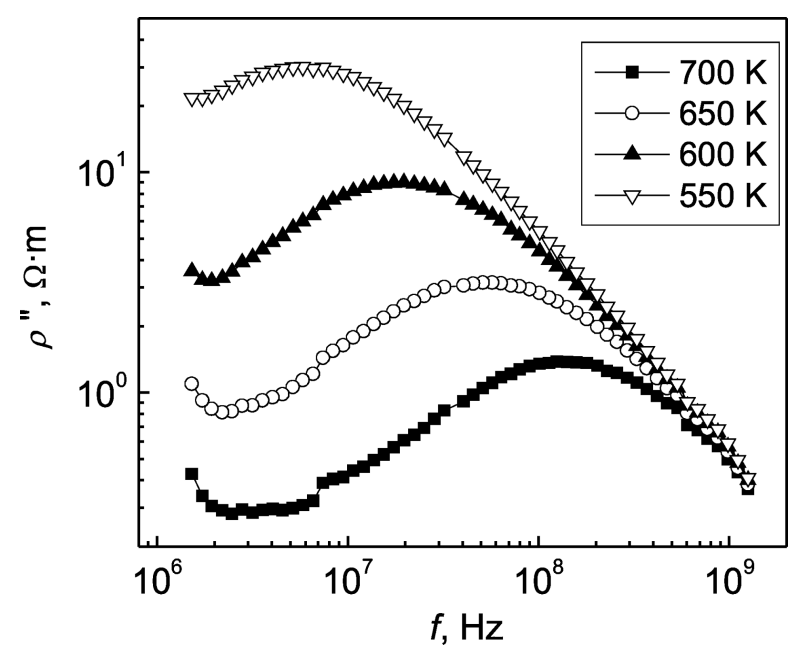

Fig. 7. Frequency dependences of the imaginary part of impedance of a GDC ceramic at different temperature.

different temperatures are presented in Fig. 7. The temperature dependences of $f_{\mathrm{b}}$ of GDC and SDC ceramics are presented in Fig. 8. The relaxation frequency $f_{\mathrm{b}}$ increases with temperature according to Arrhenius law: $f_{\mathrm{b}}=f_{0} \exp \left[\Delta E_{f} /(k T)\right]$, where $f_{0}$ is an attempt frequency related to phonon, $k$ is Boltzmann's constant. The activation energies of relaxation frequency $\left(\Delta E_{f}\right)$ were calculated from the temperature dependences of relaxation frequencies in the bulk of all investigated ceramics and the values are presented in Table 4 . The 
Table 4. Bulk ionic conductivities $\left(\sigma_{\mathrm{b}}\right)$ and their activation energies $\left(\Delta E_{\sigma}\right)$, activation energies of relaxation frequencies $\left(\Delta E_{f}\right)$, the values of dielectric permittivity measured at $100 \mathrm{MHz}$ frequency, and $\tan \delta$ of GDC, SDC, and YSZ ceramics at $650 \mathrm{~K}$.

\begin{tabular}{lccccc}
\hline Compound & $\sigma_{\mathrm{b}}, \mathrm{S} / \mathrm{m}$ & $\Delta E_{\sigma}, \mathrm{eV}$ & $\Delta E_{f}, \mathrm{eV}$ & $\varepsilon^{\prime}$ & $\tan \delta$ \\
\hline $\mathrm{GDC}$ & $1.18 \cdot 10^{-1}$ & 0.66 & 0.67 & 36.8 & 0.842 \\
$\mathrm{SDC}$ & $1.14 \cdot 10^{-1}$ & 0.66 & 0.69 & 39.4 & 0.770 \\
$\mathrm{YSZ}$ & $7.24 \cdot 10^{-4}$ & 1.00 & - & 35.8 & 0.127 \\
\hline
\end{tabular}

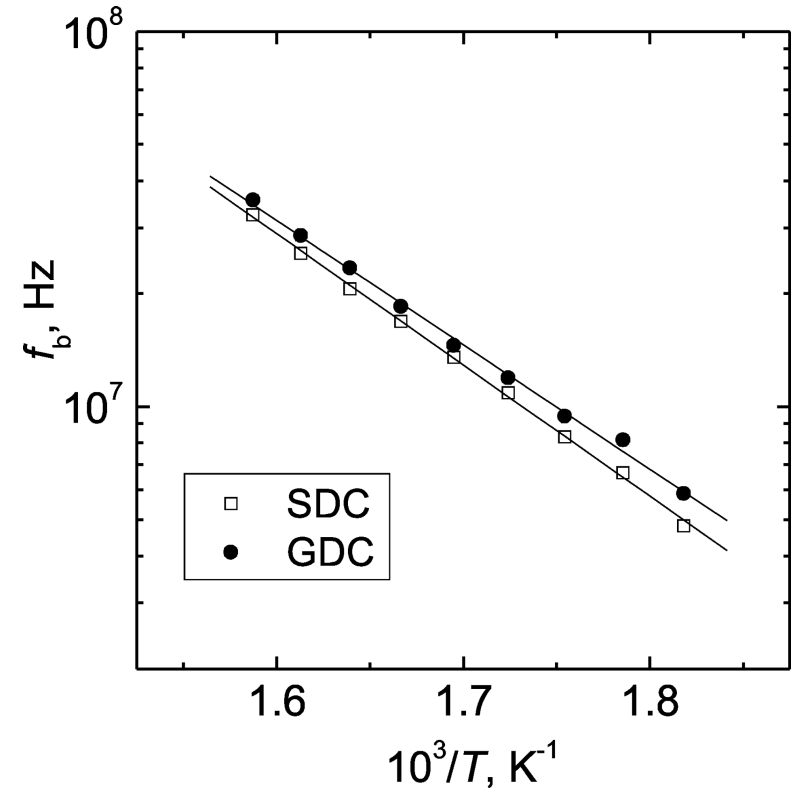

Fig. 8. Temperature dependences of relaxation frequencies in bulk of GDC and SDC ceramics.

values of $\Delta E_{f}$ are in good agreement with the values of $\Delta E_{\sigma}$. This fact leads to the conclusion that the temperature dependences of $\sigma_{\mathrm{b}}$ of the ceramics may be caused by the temperature dependence of the mobility of fast oxygen vacancies. Such ion transport peculiarities are dominant in $\mathrm{Na}^{+}$and $\mathrm{V}_{\mathrm{O}} \bullet$ SE $[15,16]$.

Temperature dependences of the dielectric permittivity and dielectric losses $\tan \delta$ were investigated at $100 \mathrm{MHz}$ frequency. In Fig. 9 the dielectric permittivity and $\tan \delta$ of GDC, SDC, and YSZ ceramics are shown as functions of temperature. The values of the permittivity of investigated ceramics may be related to the contributions of polarization of the fast oxygen vacancies' migration, vibration of lattice, and electronic polarization. The increase of $\tan \delta$ with temperature can be caused by the increase of conductivity of investigated samples.

\section{Conclusions}

GDC, SDC, and YSZ powders from the company Fuel Cell Materials were used for sintering the ceramics. The surfaces of ceramics were investigated by SEM and

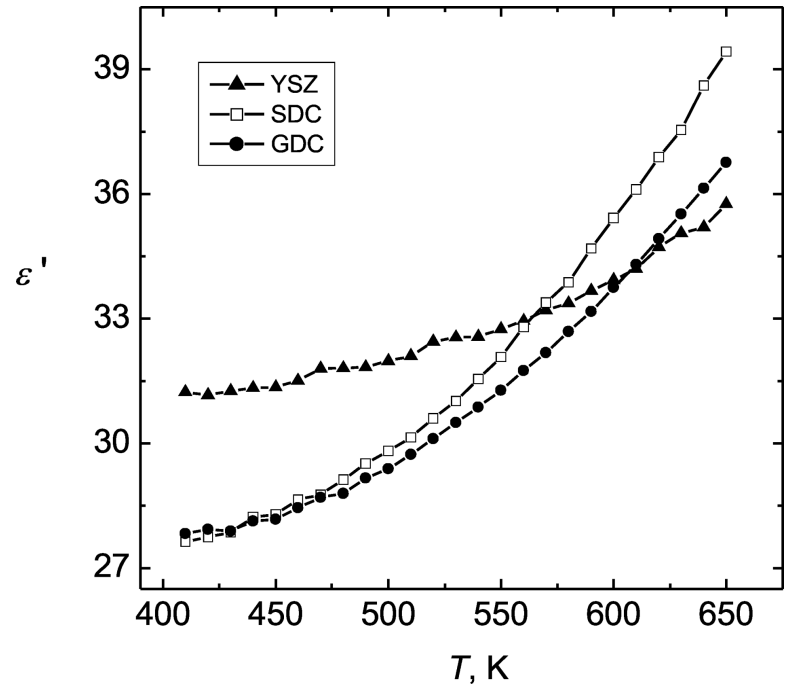

(a)

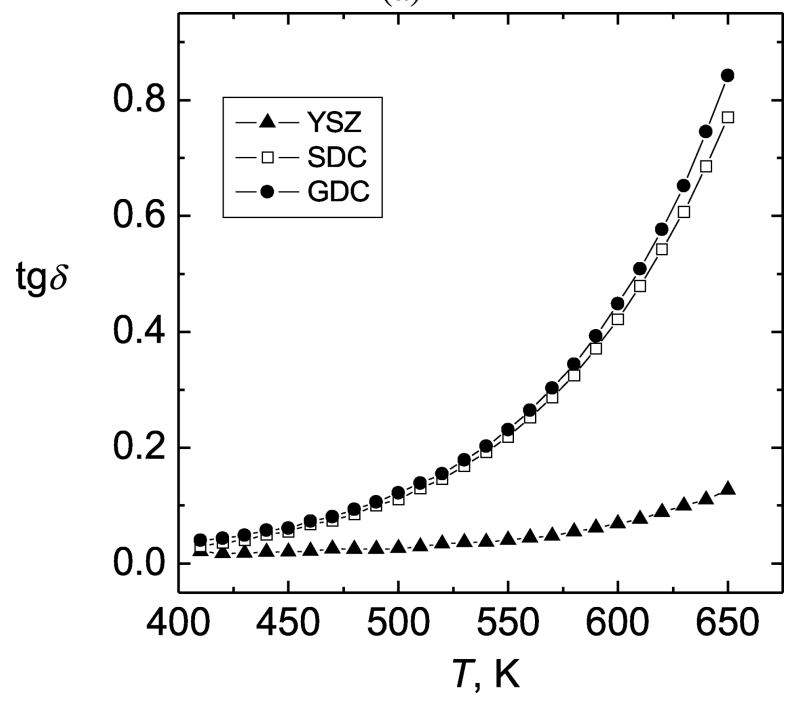

(b)

Fig. 9. Temperature dependences of (a) dielectric permittivity and (b) $\tan \delta$ of GDC, SDC, and YSZ ceramics measured at $100 \mathrm{MHz}$.

XPS. The investigation of electrical properties of ceramics was carried out in the frequency range from $10^{6}$ to $1.2 \cdot 10^{9} \mathrm{~Hz}$ and temperature range from 300 to $700 \mathrm{~K}$ by complex impedance spectroscopy. The relaxation type dispersion of electrical parameters was found. The relaxation process is presumably related to the $\mathrm{V}_{\mathrm{O}}$ •• transport in grains of the ceramics. Contribution of dif- 
ferent polarization types to dielectric permittivity of the bulk of the investigated ceramics is discussed.

\section{Acknowledgement}

This work was supported by the Lithuanian State Science and Studies Foundation.

\section{References}

[1] I. Riess, J. Power Sources 175, 325-337 (2008).

[2] J.L.M. Rupp, A. Infortuna, and L.J. Gauckler, Acta Materialia 54, 1721-1730 (2006).

[3] Yi Liu and L.E. Lao, Solid State Ionics 177, 159-163 (2006).

[4] G. Laukaitis, J. Dudonis, A.F. Orliukas, and D. Milcius, Solid State Ionics 179, 182-187 (2008).

[5] Rui-Quan Liu, Ya-Hong Xie, Ji-De Wang, Zhi-Jie Li, and Ben-Hui Wang, Solid State Ionics 177, 73-76 (2006).

[6] G. Chiodelli, L. Malavasi, V. Massarotti, P. Mustarelli, and E. Quartarone, Solid State Ionics 176, 1505-1512 (2005).
[7] W. Zając and J. Molenda, Solid State Ionics 179, 154158 (2008).

[8] D.P. Fagg, J.C.C. Abrantes, D. Pérez-Coll, P. Núñez, V.V. Kharton, and J.R. Frade, Electrochim. Acta 48, 1023-1029 (2003).

[9] Jiang Kai, Meng Jian, He Zhigi, Ren Yufang, and Su Qiang, Sci. China B 42(2), 159-163 (1999).

[10] J.L.M. Rupp, T. Drobek, A. Rossi, and L.J. Gauckler, Chem. Mater. 19, 1134-1142 (2007).

[11] J.P. Zhao, Y. Li, W.H. Xin, and X. Li, J. Solid Sate Chem. 181, 239-244 (2008).

[12] A.F. Orliukas, A. Kezionis, and E. Kazakevicius, Solid State Ionics 176, 2037-2043 (2005).

[13] D. Briggs and M.P. Seach, Practical Surface Analysis by Auger and X-Ray Photoelectron Spectroscopy (John Willey \& Sons, Chichester-New-York-BrisbaneToronto-Singapore, 1983).

[14] F. Zhang, P. Wang, J. Koberstein, S. Khalid, and SiuWai Chan, Surf. Sci. 563, 74-82 (2004).

[15] W. Bogusz, J.R. Dygas, F. Krok, A. Kezionis, R. Sobiestianskas, E. Kazakevicius, and A. Orliukas, Phys. Status Solidi A 183, 323-330 (2001).

[16] A. Orliukas, P. Bohac, K. Sasaki, and L.J. Gauckler, Solid State Ionics 72, 35-38 (1994).

\title{
DEGUONIES VAKANSIJU PERNAŠOS YPATUMAI SUPERJONINĖSE KERAMIKOSE
}

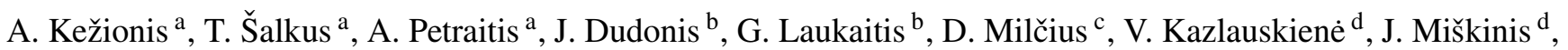 \\ A.F. Orliukas ${ }^{a}$ \\ ${ }^{a}$ Vilniaus universiteto Fizikos fakultetas, Vilnius, Lietuva \\ ${ }^{\mathrm{b}}$ Kauno technologijos universiteto Fundamentaliuju mokslufakultetas, Kaunas, Lietuva \\ ${ }^{\mathrm{c}}$ Lietuvos energetikos institutas, Kaunas, Lietuva \\ ${ }^{\mathrm{d}}$ Vilniaus universiteto Medžiagotyros ir taikomuju mokslu institutas, Vilnius, Lietuva
}

\section{Santrauka}

Pagamintos $\mathrm{Zr}_{0,92} \mathrm{Y}_{0,08} \mathrm{O}_{2}$ (YSZ), $\mathrm{Ce}_{0,9} \mathrm{Gd}_{0,1} \mathrm{O}_{2-\delta}$ (GDC) ir $\mathrm{Sm}_{0,15} \mathrm{Ce}_{0,85} \mathrm{O}_{2-\delta}$ (SDC) junginiu keramikos. Keramiku gamybai naudoti firmos „Fuel Cell Materials“ milteliai. Visu junginiu keramikos buvo kepinamos $1 \mathrm{~h} T=1773 \mathrm{~K}$ temperatūroje. Keramiku paviršiai tirti skenuojančiu elektroniniu mikroskopu (SEM) bei Rentgeno spindulių fotoelektroninès spektroskopijos (XPS) metodu. XPS tyrimų rezultatai igalino patikslinti matuotu junginiu elementinę sudètị. Parodyta, kad SDC bei GDC junginiuose be trivalenčiu $\mathrm{Ce}^{3+}$ jonų aptinkami ir keturvalenčiai $\mathrm{Ce}^{4+}$ katijonai. Kompleksinis keramiku laidis, kompleksinè varža, dielektrinè skvarba ir $\tan \delta$ ištirti $10^{6}-1,2 \cdot 10^{9} \mathrm{~Hz}$ dažnių ruože ir 300 $700 \mathrm{~K}$ temperatūrų intervale. Visuose junginiuose aptikta relaksacinè elektrinių parametrų dispersija. Ši dispersija atsiranda dèl deguonies vakansijų $\left(\mathrm{V}_{\mathrm{O}} \bullet \bullet\right)$ pernašos kietụjų elektrolitų keramikos kristalituose. 